\title{
Vefatının 500. Yılında Yavuz Sultan Selim ve Camalî Ailesi ile Münasebetleri
}

\author{
Ramazan ATA ${ }^{1}$
}

Özet: Yavuz Sultan Selim, Osmanlı Devleti'nin en önemli hükümdarlarından birisi belki de birincisidir. Kısa denilebilecek bir sürede devlet sınırlarını üç kata yakın büyüterek, yaptı̆̆ı uygulamalar ile zirve döneme taşımıştır. Safevîler ve Memlükler karşısında kazandığı zaferler ile doğu sorununu büyük oranda çözmüş ve devletin buradaki sınırlarını güven altına almıştır. Yaklaşık 750 yıllık Abbasî hilafetine son vererek bu görevi Osmanlı hanedanı üzerine almıştır. Şiî meselesi ve Mısır meselesinde en önemli danışmanları ve destekçileri Cemalî Ailesi’nin birer üyesi olan Osmanlı'nın iki ve üç numaraları Veziriazam Pîrî Mehmed Paşa ve Zenbilli Ali Efendi olmuştur. Bu iki devlet adamının destekleri ile Şiî tehdidi altında dağılma noktasına gelen devleti kökten çözümlerle tekrar zirveye çıararak dünyanın en büyük devleti haline getirmiştir. Tarihin en sert yöneticilerinden birisi olmasına rağmen Pîrî Mehmed Paşa ve Zenbilli Ali Efendi ile genellikle saygın bir iletişimi olmuştur. Bu saygının nedeni onların âlim bir ailenin saygın üyeleri olarak devletin bekası için gösterdikleri bitmez tükenmez gayretleri olmalıdır. Aslında Safevîler, Osmanlılar için daha önce devleti dağılmanın eşiğine getiren Timur istilasından daha tehlikeliydi. Çünkü bunlar Anadolu'daki göçebe Türkmenler tarafından da gönülden destekleniyorlardı. Ama tehlikenin büyüklügünü çok iyi bilen Cemalî Ailesi üyelerinin Yavuz tarafından önemli görevlere getirilmesinin katkılarıyla idarî, dinî ve tasavvufî alanlarda alınan tedbirler bu tehlikenin yayılması engellemiştir. Özellikle Cemalî Ailesi’nin tarikatı diyebileceğimiz Halvetîlik Şiîliğin Anadolu’da yayılmaması konusunda koruyucu bir aşı görevi görmüştür.

Anahtar Kelimeler: Osmanlı Devleti, Yavuz, Pîrî Mehmed Paşa, Zenbilli Ali Efendi.

\section{Yavuz Sultan Selim and Relationships with Cemalî Family on The 500’th Years of Died}

Abstract: Yavuz Sultan Selim is one of the most important rulers of the Ottoman Empire, perhaps the first. In a short period of time, the state has enlarged its borders nearly three times and brought it to the peak period with its applications. With his victories over the Safavids and Mamluks, he solved the eastern problem to a great extent and secured the borders of the state here. By ending the 750 years Abbasid caliphate, he took this task over the Ottoman dynasty. The most important advisors and supporters of the Shiite issue and the Egyptian issue were the Grand Vizier Piri Mehmed Pasha and Zenbilli Ali Efendi, the two and three numbers of the Ottoman Empire, who were members of the Jamali Family. With the support of these two statesmen, he brought the state, which came to the point of disintegration under the Shiite threat, back to the top with radical solutions, and made it the world's largest state. Although he was one of the toughest rulers in history, he had generally a respectable communication with Piri Mehmed Pasha and Zenbilli Ali Efendi. The reason for this respect must be their endless efforts for the survival of the state as respected members of a scholarly family. In fact, the Safavids were more dangerous for the Ottomans than the Timurian invasion, which had previously brought the state to the brink of collapse. Because they were supported wholeheartedly by the nomadic Turkmen in Anatolia. However, the measures taken in the administrative, religious and mystical fields with the contribution of Yavuz assigning members of the Cemali Family, who knew the magnitude of the danger very well, prevented the spread of this danger. Especially Halvetîlik, which we can call the order of the Cemali Family, served as a protective vaccine against the spread of Shiism in Anatolia.

Key Words: Ottoman State, Yavuz, Pîrî Mehmed Pasha, Zenbilli Ali Efendi.

${ }^{1}$ Orcid ID:0000-0002-8925-0289 Doç. Dr., Aksaray Üniversitesi İIF., İslam Tarihi Anabilim Dalı, ataramazan68@gmail.com. 


\section{Summary}

Yavuz Sultan Selim is the 9th ruler of the Ottoman Empire and was enthroned in a very critical period. The most important reason why he rebelled against his father and wanted to become a sultan is the Shiite problem, which became a matter of survival for the state. Step by step, Shah Ismail, who came to power in Iran, used the Shi'ism to expand his state, and at this point he received the most important support from the nomadic Turkmens within the Ottoman borders. Some of these Turkmens supported this process by migrating from Anatolia to Iran. Although he informed his father about the difficulties that this process would cause for the state from an early period, he could not get any results and he took action himself. Yavuz Sultan Selim 's main goal in the period when he ruled the state was to suppress the Safavids. In turn, it has been to strengthen Sunnism. The Cemalî family gave him the most important support in this regard. Seeing the branch of the Cemalî family living in Amasya, he understood that Shiism was a great threat to the Ottoman Empire, but he had difficulty in explaining this to the governor of Amasya, Prince Ahmed. Therefore, in his struggle for the throne with his brother, It supported II. Bayezid as well as I. Selim. Yavuz Sultan Selim maintained good relations with the members of the Cemalî Family, whom his father had known since Amasya governorship, after he was enthroned. Aware of the problem in combating the Safavids, Sheikh al-Islam Zenbilli Ali Cemalî Efendi constantly sided with Yavuz Sultan Selim and approved the Iran campaign with his fatwas. The fact that a very close relative was killed by Shiites in Amasya had already made him aware of this issue.

Zenbilli Ali Efendi, He carefully followed the development of the Shiite issue and its becoming a matter of survival for the state since his appointment to Sheikh al-Islam by II. Bayezid . Therefore, from the moment he took the throne, Zenbilli Ali Efendi gave Yavuz the greatest support for his Iran expedition. . The fact that Piri Mehmed Pasha, a member of the Cemali family, another important statesman, became a vizier after the Çaldıran war and became a grand vizier after the Egyptian Campaign, made this family the most important ruling family of the Ottoman classical period. Both statesmen agreed that the Safavid threat should be the top priority of the state. After the Çaldıran Victory, it was Pîrî Mehmed Pasha, who organized the Sunnî Kurds in the Eastern and Southeastern Anatolia regions and formed a line of protection against the Safavid threat. Thanks to this line, the Shia of the region was prevented. It was Zenbilli Ali Efendi who gave a fatwa to the war against the Mamluks who wanted to confine the Ottoman Empire to Anatolia by cooperating with the Shiite Safavids. Iran fight that the fatwa, saying that their mülhid, Zenbilli Ali Efendi Sunni Mamelukes ' against what is mülhid was also supporting Mülhids, he gave the fatwa. Thus, these two members of the Jamali Family became the most important supporters of the Iran and Egypt expeditions in terms of religion and administration.

These two valuable scholars and statesmen of the Jamali family not only supported the state on the issue of Iran and Egypt, but also took very far-sighted measures on the other two important problems of the period, the Shiite and the Crusaders. In order to prevent the Shiite threat from spreading in Anatolia, the Halvetî sect was considered by this family as an antidote. Both Halvetî and Safavî sects originate from Ardebil Tekke. Although Safavid emerged as a Sunni sect, it was Shiited for political purposes in the later period. For this reason, even though the Halvetism was met with suspicion by Yavuz Sultan Selim, members of the Cemali Family and some other members of this order persuaded Yavuz about the importance of Halvetism. Halvetism, which emerged in the same place with him, played an important role in the Islamization of Anatolia and the Balkans. Cemalîlik, which is the most important branch of Halvetism in Anatolia, was spread in Istanbul by Cemal Halvetî, a member of this family. Cemaleddin İshak Karamanî, the other important Halvetî sheikh, played an important role in the spread of this sect in Istanbul and the Balkans.

Another reason for Yavuz Sultan Selim's Egypt expedition was to prevent the Portuguese who came to the region from the south from invading the holy lands. The Portuguese had reached the Indian Ocean by traveling 
from the south of Africa with the progress they made in maritime. From here they started to threaten the Islamic world. In fact, rumors were circulating that they would attack Mecca and Medina. Yavuz Sultan Selim, who learned this, asked Piri Mehmed Pasha to take measures to prevent this. Pasha was quick to realize that the most important way to prevent the new threat was through new ships and their equipment. Taking advantage of his assignment as the guard of Istanbul, he immediately prepared the shipyards for new shipbuilding and equipment. In these navies, he had ships with the qualifications and equipment that Yavuz wanted in a short time and shipped them to Egypt in a short time. Piri Mehmed Pasha showed his skill in technology by mounting the most advanced cannons of the period in the navy he sent to Egypt. During the Egypt expedition, he carried out the guard of Istanbul perfectly and sent the ships that Yavuz wanted to send to Egypt in a short time in Istanbul shipyards showed that he was a competent statesman. In addition, according to some historians, this fleet, which was sent to Egypt and equipped with the most advanced cannons of the period, discouraged the Portuguese, who had reached the Red Sea by wandering through the Cape of Good Hope, from the idea of attacking Mecca and Medina.

Keywords: Yavuz Sultan Selim, Cemalî Family, Zenbilli Ali E fendi, Pîrî Mehmed Pasha.

\section{GíRiş}

Nasıl Bermekîler Ailesi Abbasilerin, Nizamülmülk Ailesi Selçukluların zirve dönemleri ise Cemalîler Ailesi de Osmanlıların zirve dönemidir. Osmanlı'nın zirve dönemi diyebileceğimiz II. Bayezid, Yavuz ve Kanunî dönemlerinde; Cemal Halvetî (ö. 1497) tasavvuf alanında, Pîrî Mehmed Paşa (ö. 1532) idare alanında, Zenbilli Ali Efendi (ö. 1526) ise ilmiye alanında Osmanlı Devleti'ne ve padişahlarına yön vermişlerdir. I. Selim çocukluğundan itibaren Amasya ve İstanbul'da bu aile mensuplarını yakından tanıma imkânına sahip olmuştur. Özellikle Pîrî Mehmed Paşa ve Zenbilli Ali Efendi, Yavuz'un doğuya yönelmesinde en önemli teşvikçileri ve destekçileri durumuna gelmişlerdir. Hayatı boyunca onları görevlerinde tuttuğu gibi görüşlerine de son derece itibar etmiştir. Vefat ettiği tarihe kadar görevde tuttuğu en önemli görevliler devletin iki ve üç numarası diyebileceğimiz Pîrî Mehmed Paşa ve Zenbilli Ali Efendi olmuştur.

Yavuz Sultan Selim (ö. 1520) Osmanlı ve Türk tarihinin en önemli hükümdarlarından birisidir. Yaklaşık 8 yıllık hükümdarlığında Osmanlı Devleti'ni iki kattan fazla büyütmüş ve devleti sağlam temeller üzerine oturtmuştur. Meydana getirdiği son derece disiplinli sitemle, hayatının önemli bir bölümünü seferlerde geçirmesine rağmen, devlette neredeyse hiçbir otorite boşluğu oluşmamıştır. Atadığı görevlileri son derece iyi seçmiş ve görevini aksatanlara karşı son derece sert davranmıştır. Başta vezirler olmak üzere birçok bürokratı idam ettirmekten çekinmemiştir. Bundan dolayı atadığ son sadrazamı olan Piri Mehmed Paşa sürekli hayatından endişe içinde yaşamaktan usanarak birgün Yavuz'a şöyle demiştir: "Padişahım bilirim, nihayet bir bahane ile beni öldürürsün. Ĕger öldüreceksen bir gün evvel bizi dünya hayatından halas etsen çak makul olur idi. ” Buna karşı Yavuz Sultan Selim gülerek şu manalı cevabı vermiştir: "Benim de bu husus çoktan beri hatırımdadır. Ancak yerini tutar adam bulunmaz ve vezaret hizmetini olduğu gibi tutacak adamın var olduğu yakinen bilinmez. Yoksa seni de muradına vasıl iderdim. Kolay iştir." (Solakzâde, 1989: 104-105)

Yavuz Sultan Selim'in genel uygulamalarının sertliğine baktığımız zaman bu sadrazam ve şeyhülislama karşı son derece saygılı davranması ve görüşlerine itibar etmesi oldukça dikkat çekicidir. Öyleyse bu devlet adamlarında onun saygısını celbeden özellikler olmalıdır. Yavuz, Aksaraylı âlimleri ilk olarak babasının Amasya Valiliği döneminde tanımış olmalıdır. Aksaray 
kökenli olan Cemalîler Ailesi göç ettiği Amasya'nın önde gelen ailelerinden birisiydi. II. Bayezid'in başta Cemal Halvetî olmak üzere Aksaraylı mutasavvıf ve âlimleri Amasya Valiliği döneminde tanıdığını ve hükümdar olunca bunları İstanbul'a getirttiğini biliyoruz. Bu çalışmamızda önce Yavuz'un Aksaray'a gelmesini kısaca anlattıktan sonra bu iki Aksaray menşeli devlet adamı ve âlim olan Pîrî Mehmed Paşa ve Zenbilli Ali Efendi ile saygın ilişkilerini ve nedenlerini ortaya koymaya çalışacağız.

\section{YAVUZ SULTAN SELIM DÖNEMINNE AKSARAY VE CEMALÎ AİLESİ}

Yavuz Sultan Selim, Mısır seferinden dönerken Aksaray’a uğramış ve burada 4 gün kalmıştır (Konyal1, 1974: 591). Eskil'in köylerinden olan Kökez de bu dönemde yaşayan ve Yavuz'un ordusuna büyük zarar veren Karamanoğulları'ndan Kökezoğlu isimli birinden ismini almaktadır (Konyalı, 1974: 592-593). Kayıtlara göre Yavuz Sultan Selim zamanında Aksaray'ın toplam 109 köyü vardır. Bu 109 köyde toplam 3100 aile reisi yaşamaktadır. Bunu bir eş ve dört çocukla çarptığınız zaman 15500 sayısı çıkmaktadır. Yani o dönemde nüfusun yüzde sekseni kırsal kesimde yaşamaktadır diye düşünebiliriz. Ayrıca köylerden daha az da olsa insanlar hayvanlarını otlatmak için uzun süre mezra ve kışlaklarda kalmaktaydılar (Konyalı, 1974: 586-589).

Bu durum şehrin niçin bu dönemde önemsiz hale geldiğini çok iyi göstermektedir. Anadolu Selçuklu Devleti zamanında ticaret yollarının merkezinde bulunan ve başkent Konya'ya çok yakın olan Aksaray önemli bir şehirdi. Fakat Osmanlı Devleti döneminde hem bu özelliğini kaybetti hem de Fatih döneminde Karamanoğlu taraftarlığı ile yaftalanarak bütün kalifiye nüfusunu kaybetti. Münşeat-1 Selâtin'de Feridun Bey, Yavuz'un Çaldıran ve Mısır seferi gidiş-dönüşünde takip ettiği yollarla ilgili bilgi verir. Bu bilgiye göre Yavuz, Çaldıran Savaşına giderken Eskil'in Karapınar ve Ereğli’ye yakın olan topraklarına uğramıştır. Mısır seferinden dönerken 1516-1517 yılında Aksaray'a uğrayarak dört gün dinlenmiştir (Konyalı, 1974: 590-591).

Şikari’nin yazdığı Karamanoğulları tarihine göre, Mısır seferi dönüşünde Yavuz, Aksaray civarında Karamanoğlu saldırısına uğramıştır. Karamanoğlu Kasım Bey liderliğinde Osmanlı ordusunun arkadan saldırıya uğradığı belirtilir. Bu saldırıyı gerçekleştiren ise 10 bin süvari ile gönderilen Kökezoğlu isimli bir Karamanoğlu komutanıdır. Bu saldırıları bastırmak isteyen Yavuz ordusu ile gelip Aksaray'da konaklad1. Larende ve çevreye askerler gönderdi. Larende yeniden Osmanlı askerlerinin eline geçti ve saldırıyı gerçekleştirenler Bulgar Dağı'na kaçtılar (Konyalı, 1974: 592). Karamanoğullarının Yavuz döneminde Osmanlı ordusuna 10 bin süvari ile saldırabilecek kadar güçlü olması, Anadolu'nun halen Osmanlı Devleti tarafından tam olarak kontrol edilemediğini göstermektedir. Kanunî döneminde gerçekleşecek olan isyanlar da bu görüşümüzü desteklemektedir.

Cemalîler dediğimiz aile Hz. Ebubekir ve Fahreddin Razî neslinden gelerek, 1389 yılında Aksaray’da vefat edip Ervah kabristanında medfun bulunan Cemaleddin Muhammed Aksarayî hazretlerine dayanmaktadır. Bu ailenin fertleri, II. Bâyezid, Yavuz ve Kanunî dönemlerinde toplum ve devlet adamına önemli bir canlılık getirmişlerdir. Kardeşler arası iktidar mücadelesinde Türk kültürüne sahip çıkan Yavuz'u destekleyip danışmanlık yapmışlardır. (Küçükdağ, 2018: 166). Hoşgörü medeniyeti diyebileceğimiz bu düşüncenin temel taşlarını dinî, tasavvufî̀ ve siyasî alanda çizenlerin en etkililerinden birisi II. Bâyezid, Yavuz ve Kanunî dönemlerinde yaşayan Cemalîler ailesi olmuştur. Her yönüyle Selçuklu Devleti'nin devamı olan Osmanlı Devleti’nin kısa sürede Beylikler arasından sıyrılıp sivrilmesinin nedeni askeri başarısı kadar üstün dehası ile kurup geliştirdiği devlet teşkilatına 
ve âlimlere verdiği değere dayanır. Cemalîler Ailesi'nin genetik kodlarını çözmek Osmanlı klasik döneminin başarılı yönetiminin şifrelerini de çözmemizi sağlayacaktır.

Bilinmesi gereken önemli bir konu da Aksaray orijinli olan Cemalîler Ailesi'nin neredeyse hepsinin yolunun Amasya'dan geçmesidir. II. Bâyezid ve Yavuz bu aile üyeleri ile şehzadeler şehri Amasya'da tanışmıştır. Öyleyse bu aile üyeleri daha önceden bir şekilde Amasya'ya gelmişlerdir. Cemalîler Ailesi'nin Amasya’ya gelmesi Cemaleddin Aksarayî döneminde olmuştur. Cemaleddin Aksarayî samimi arkadaşı Amasyalı Şadgeldi Paşa'nın daveti ile oraya gitmiş ve onun bağımsızlığını ilan etmesinden vefatına kadar yaklaşık 20 yıl (1361-1381) orada kalmış ve önemli görevlerde bulunmuştur. Burada Amasya ve Tokat civarının dikkat çekici bir özelliğini hatırlamakta yarar vardır. Bildiğimiz gibi bu şehirler Türkler'in Anadolu'daki ilk yerleşme bölgelerinden olmuştur. Tokat ve Amasya o dönmede Danişmend ili olarak bilinip Türkmen ağırlıklıydı. Danişmendliler ise Harzem kökenli bir aile olarak ilme ve medreselere büyük önem vermekteydiler. Daha doğu taraflar ise başta Malatya olmak üzere kozmopolit bir yapıda ve Farisi özellikler taşıyordu (Bayram, 2008: 3).

Amasya şehri dedelerinden dolayı daha sonraki dönemde de Cemalîler ailesi için önemini korumuştur. Cemaleddin Aksarayî önce Konya'ya ardından Aksaray’a döndükten sonra da burada bazı aile üyeleri kalmıştır. Bunun yanı sıra Amasya şehrini tekrar Cemalîler Ailesi için çekici hâle getiren bu şehrin Osmanlı Devleti’nin şehzadeler şehri olmasıdır. Bazıları tarafından söylendiği gibi bu durum, Aksaray Osmanlı Devleti sınırlarına katıldıktan sonra zorla nakil ve iskânla olabileceği gibi, özellikle II. Bâyezid döneminde, onun ilme ve âlime değer veren şahsiyetinden dolayı Amasya'nın bilgi ile uğraşanlar için cazibe merkezi olmasından dolayı da olabilir. Bu durumu Pîrî Mehmed Paşa'nın babası Cemal Halvetî’nin şeyhi tarafindan bu şehre gönderilmesi desteklemiştir. Bundan dolayı bu ailenin okumuşlarından bazıları 1470 yılından sonra Amasya şehrine gitmiş olmalıdır. Amasya'da mühim görevlere getirilmeleri de bu durumu desteklemektedir. II. Bâyezid'in padişah olmasıyla durum değişmiş aile için İstanbul cazibe merkezi haline gelmiştir. Cemalî Ailesi üyeleri Aksaray, Karaman ve Konya’nın eski önemini kaybetmesinden dolayı artık Amasya'ya değil İstanbul'a gitmeye başlamışlardır. Şehzade Ahmed'in valiliği sırasında Amasya'da Şiiliğin etkisinin artması hatta Cemalîler Ailesi'nden ve Zenbilli Ali Efendi'nin kardeşi Muhyiddin Mehmed Çelebi'nin 1503 yılında bir karışıklık sırasında Şiilik karşıtı vaazları nedeniyle öldürülmesi İstanbul'a göçü iyice hızlandırmıştır (Küçükdağ, 2017: 4).

\section{YAVUZ SULTAN SELIM VE PÎRÎ MEHMED PAŞA}

II. Bayezid 1481yılında Osmanlı tahtına oturunca Amasya'da yakın çevresinde olup güvendiği kimselerden bazılarını İstanbul'a getirtmiştir. Bunlardan birisi de âlim, bilgin ve güvenilir bir kimse olan Seyyid Ömer Efendi'dir. Padişah onu kendisine Arpa Emini yani Ticaret Bakanı yapmıştır. Seyyid Ömer Efendi, İstanbul' da Yayla civarında 1490 yılında bir cami yaptırdı. Seyyid Ömer Efendi aynı zamanda Pîrî Mehmed Paşa'nın eşi Fatma Hanım'ın babasıdır. Bundan dolayı damadını padişaha karşı övmüş ve önemli görevlere getirilmesi için teşvik etmiş olmalıdır. Seyyid Ömer Efendi 1485 yılında damadı ile babası Cemal Halvetî’nin İstanbul'a getirilmesi yönünde padişaha telkinlerde bulunmuştur (Konyal1, 1974: 2591).

Pîrî Mehmed Paşa, II. Bayezid'in tahta çıkmasından sonra İstanbul'a gelmiştir. Aklî ve naklî ilimlerde büyük gelişmeler göstermiş, dedelerine ve babasına layık mükemmel bir şekilde yetişmişti. İstanbul'a gelince ilk olarak ne yapmış olduğunu bilmiyoruz ama daha sonra ailesinden çoğunun olduğu gibi kadılık mesleğine intisap etmiştir. 1498 yılında bir hüccete imza koymasından bu tarihte kadı olarak 
bulunduğunu anlıyoruz. Sırasıyla Sofya, Silivri, Serez, Galata kadılıklarında bulunmuştur. Bir kaynakta kadı iken günlük 150 akçe yevmiye aldığı belirtilmektedir ki, bu zamanın şartlarına göre Şeyhülislam maaşına denk gelen çok yüksek bir ücrettir (Konyalı, 1974: 2592). Bazı batılı kaynaklar bu dönemlerde Şehzade Süleyman'a da hocalık yaptığını belirtmektedirler (Downey, 1975: 4).

Pîrî Mehmed Paşa, II. Bayezid'in hükümdarlığının sonlarına doğru kadılıktan ayrılarak maliye teşkilatına girmiştir. Niçin böyle bir değişikliğe ihtiyaç duyduğunu bilmiyoruz ama bu dönemde kılı kırk yaran bir dikkatle Allah rızasını gözeterek görevini yaptığını biliyoruz. 1504 yılında Maliye teşkilatına geçti ve Hazine Defterdarlığında göreve başladı. 1505 yılında Anadolu Defterdarı olarak görevlendirildi (Küçükdağ, 2017: 24). Şah İsmail'in Şiîliği yaymak için daîlerini Osmanlı ülkesine sızdırdığı ve kansız şekilde Osmanlı ülkesini ele geçirmek istediği dönemler yaşanıyordu. Yavuz ya buna gerekli cevabı verecek ya da ülkesinin elinden kayıp gitmesini izleyecekti. I. Selim'in karakteri, lakabı olan Yavuz'dan da anlaşılacağı gibi, böyle bir duruma seyirci kalmaya uygun değildi. Yavuz 1512 yılında Şiî tehdidine karşı gerekli tedbirleri almayan babasını bertaraf ederek Osmanlı tahtına oturdu. Yeni padişah Yavuz'un önündeki en önemli engel kardeşi Ahmed idi. Özellikle devşirme devlet adamları Şehzade Ahmed'i destekliyordu. Yavuz kardeşini nasıl bertaraf edebileceğini düşünürken en önemli danışmanı olan Defterdar Mehmed Çelebi'den yardım istedi. Pîrî Mehmed Çelebi şöyle dedi: “... Sultan Ahmed'in dimă̆ı saltanattan henüz hâli değildir. Asitane-i saadetiniz hüddamın cümlesi kadimden anlar canibine mensublar idi. Muahedeleri peyvend-i muhkem olmuşdu. Ayan-ı hademe-i südde-i vâlâ tarafindan anlara mektuplar tesvid olunub gönderilsün. Ümiddir itimad idüb harice meyl etmeye." (Celal-Zâde, 1990: 103).

Şehzade Ahmed'e destekçilerinin ağzından savaşa teşvik mektupları yazdırma fikri Yavuz'un aklına yattı. Bu mektuplara inanan Amasya Valisi Şehzade Ahmed ordusunu toplayarak Bursa yakınlarına kadar geldi. Fakat burada mektuplarda belirtilen desteği göremeyerek aldatıldığını anladı. Artık istemese de Osmanlı ordusu ile savaşa girmekten başka çaresi kalmamıştı. Yapılan savaşta ordusu kısa zamanda dağılarak bozguna uğradı. Kendisi yakalanarak yay kirişiyle boğduruldu. (Celal-Zâde, 1990: 249-250). Böylece Pîrî Mehmed Paşa yeni hükümdar Yavuz'u büyük bir beladan kurtararak onun en gözde adamları arasına girdi. Bundan bir süre sonra yönetimdeki başarısıyla kendisini ispat edince makamı yükseltildi.1514 yılında Rumeli Defterdarı yani Maliye Bakanı yapıldı. Yavuz Sultan Selim, Osmanlı ordusu ile birlikte İran'a doğru yol alırken Pîrî Mehmed Paşa da Rumeli Defterdarı olarak Başdefterdarlık göreviyle Çaldıran Savaşı'na katıldı. Savaş sürecinde Başdefterdar olarak askerin iaşesi yanı sıra menzil hizmetlerinin gerçekleştirilmesiyle de görevlendirilmiştir. Yolun uzun ve yolculuğun zor olmasından dolayı Yavuz'un fazlasıyla endişelendiği askerin iaşe ve ibate işini başarıyla halletmiştir (Konyalı, 1974: 25-28).

Pîrî Mehmed Paşa'nın Çaldıran savaşındaki hizmeti sadece bununla sınırlı değildir. Ayrıca Çaldıran'a gidilirken Aksaraylı olmasından dolayı iyi bildiği Anadolu yollarında da askerin kolaylıkla ilerleyip zafer kazanması için her türlü imkânı değerlendirmiştir. Burada Konya ve civarında medfun evliya ve sulehanın makamlarını da onartmıştır. Aç ve muhtaç olanların ihtiyaçlarını gidermiş, savaşın sonucunun ne olacağını Konya'ya uğrayarak daha önce Edirne'den tanıdığı Mevlana dergâhı postnişini Sinan Dede'den sormuştur (Tansel, 1969: 41). Sinan Dede savaşı Osmanlı ordusunun kazanacağ1 yönünde işarette bulunmuş, Yavuz Sultan Selim eğer bu işaret gerçekleşirse dönüşte dergâha hizmette bulunacağına dair adakta bulunmuştur. Dönüşte de bu adağı yerine getirmiştir (Küçükdağ, 2017: 29). 
Pîrî Mehmed Paşa ordunun iaşe ve ibata ihtiyacını eksiksiz karşılamak için Yavuz'dan önce yola çıkarak hızlı bir şekilde Amasya'ya ulaştı. Bu yolculukta Aksaray’a uğramış olması gayet muhtemeldir. Amasya'dan kısa sürede tedarik ettiği zahire ve mühimmatı alıp Sivas'a varan Yavuz komutasındaki orduya katıldı. Sivas'tan sonra ordu İran yönünde uzun süre yürümesine rağmen Şah İsmail'den hiçbir haber alınamadı. Yolculuğun uzunluğu ve zorluğu nedeniyle ordu'da sızlanmalar başlasa da Yavuz'un dirayeti ile sefer devam etmiştir. Hatta Yavuz bu süreçte sızlanmaları kendine aktaran ve dönmeyi teklif eden Karaman Beylerbeyi Hemdem Paşa'yı idamdan dahi çekinmemiştir (Küçükdağ, 2017: 30). Fakat bu sızlanmalar kesilmeyince durumu en güvendiği devlet adamı olan Pîrî Mehmed Paşa ile değerlendirmeye karar verdi. Pîrî Mehmed Paşa düşman hakkında bilgi toplanarak ona göre hareket edilmesinin en doğru yol olacağını belirtti. Bazı önemli komutanlar ve casuslar İran tarafının durumunu tespitle görevlendirildiler. Bunlar yaptıkları araştırmaları sonucunda Şah İsmail'in Hoy'da bulunduğunu tespit ederek padişaha bildirdiler (Küçükdağ, 2017: 31).

Bunun üzerine Osmanlı ordusu hızlı bir yürüyüşle 23 ağustos 1514 günü Çaldıran Ovası'na vardı. O gece hemen harp meclisi toplandi. Askerlerin yorgun olmasından dolayı Çaldıran'da savaşa hemen başlanıp başlanmamasıyla ilgili tartışma yapıldı. Çoğunluk ordunun yorgun olduğu bu nedenle bir süre dinlendikten sonra savaşa başlaması gerektiği fikrini savundu. Başdefterdar diğer çoğunluğun tersine olarak düşmana firsat verilmeden hemen savaşa başlanmasını isteyen görüşü ile Yavuz'un takdirini kazandı ve onun şu övgüsüne mazhar oldu, "-İste yegâne rey sahibi adam! Yazık ki vezir olamamış!" Pîrî Mehmed Paşa'nın gayet doğru olan görüşü de dikkate alınarak hemen savaşa başlandı ve savaş kısa sürede başarı ile sonuçlandırıldı (Konyalı, 1974: 2595; Küçükdağ, 2017: 3132).

Çaldıran Zaferi'nin kazanılmasında Osmanlı ordusunun teknolojik üstünlüğünün büyük etkisi olmuştur. Safevîlerin güçlü süvarileri Osmanlı ateş gücü karşısında atları ürkerek kaçmaya başlayınca çaresiz kalmıştır. Savaş sonunda Safevî ordusunun birçok komutanı ve Şah İsmail'in eşi de ele geçirilenler arasında bulunmuştur (Turan, 1980: 402). Pîrî Mehmed Paşa, Çaldıran zaferinden sonra, Padişah tarafından yeni ele geçirilen Tebriz'de bulunan Şah İsmail'in hazine ve mallarına el koyup muhafaza altına almak için vezir Dukakinoğlu Ahmed Paşa ve ünlü tarihçi İdris-i Bitlisî ile beraber buraya gönderildi (Küçükdağ, 2017: 26-27). Bunların gerekli önlemleri almasından sonra Yavuz Sultan Selim, Tebriz'e geldi. Yavuz'un niyeti o kışı Tebriz'de geçirerek ilk firsatta Şah İsmail'i ortadan kaldırmaktı. Fakat askerin iaşe ve ibata imkânsızlıkları ile İstanbul'a dönme istekleri buna müsaade etmedi. Hüner sahibi insanlardan bin kadarının İstanbul'a götürülmesini istedi (Solakzâde, 1989: 30).

Yavuz, Çaldıran Zaferi sonrasında bölgede bir süre kalarak Şiîlik ve Şah İsmail meselesini kesin bir çözüme kavuşturmak istiyordu. Fakat Tebriz'de sadece 9 gün kaldıktan sonra ayrılıp Anadolu'ya dönmek için Nahcivan'a gelindiğinde durum iyice zorlaştı. Asker yiyecek ve giyecek sıkıntısından şikâyet etmeye başladı (Celal-Zâde, 1990: 154-155). Bütün bu sıkıntılardan usanan Yavuz 22 Eylül 1514 tarihinde Mustafa Paşa'dan boşalan vezirliğe Pîrî Mehmed Paşa’yı atadı (Küçükdağ, 2017: 33).Pîrî Mehmed Paşa, Bayburt yöresinden sağladığı erzak ile kısa sürede askerlerin yiyecek ihtiyacını karşıladı ve Yavuz'u iyi bildiği Amasya'ya gitme konusunda ikna etti. Yavuz, kış bastırmadan hızlı bir yürüyüşle Amasya'ya ulaşstı ve buradaki saraya yerleşti. Burada Hersekzâde'den boşalan sadrazamlığa Dukakinoğlu Ahmed Paşa'yı getirmesi devşirme devlet adamları ve yeniçeriler arasındaki huzursuzluğu artırdı. Devşirme devlet adamları tarafından kışkırtılan bazı yeniçeriler Pîrî Mehmed Paşa ile padişahın hocası Hilmi Çelebi’nin kaldığı evlere 22 Nisan 1515 gecesinde zarar 
verdiler. Her ikisi de şans eseri canlarını kurtarabildiler. Bu durum Yavuz'un çok zoruna gitti ve İstanbul'a dönünce bunu yapanları ortaya çıkararak cezalandırdı (Solakzâde, 1989: 30).

Amasya'da gerçekleşen bu saldırıda Pîrî Mehmed Paşa ile padişahın hocasının hedef seçilmesi anlamlıdır. Yavuz'un bu konulardaki tavrını bilen saldırganların meseleye ölüm kalım mücadelesi olarak baktıkları anlaşılmaktadır. Bu saldırı basit bir geri dönüş isteğinin tezahürü değil derin siyasi hedeflerin gerçekleştirilme talebidir. Yavuz Sultan Selim'in önemli görevlere devşirme olmayanları getirmesi bunları endişelendirmiş ve böyle bir saldırıya yöneltmiş olmalıdır (Küçükdağ, 2017: 2930). Padişah İstanbul'a dönmeye karar verince önce Konya'ya hareket etti. İran seferine giderken kendisine zaferi müjdelemiş olan Mevlevi şeyhi ziyaret etmek istiyordu. Bunun için aracı olarak Pîrî Mehmed Paşa'yı gönderdi. Sinan Dede çeşitli nedenlerle bunu kabul etmedi. Yavuz en azından ne istiyorsa yerine getirmek istediğini Paşa aracılığı ile tekrar bildirdi ve Sinan Dede'nin Mevlana Dergâhı ile ilgili isteklerini yerine getirdi. Padişah ile Pîrî Mehmed Paşa İzmit koyundan İstanbul'a aynı Saltanat kayığı ile döndüler (Küçükdağ, 2017: 30).

Yavuz, Amasya'da en sevdiği iki kişiye yapılan suikastın müsebbiplerini cezalandırmak için İstanbul'a döner dönmez harekete geçti. Amasya'da gerçekleşen saldırı olayının açığa çıkarılması amacıyla bizzat padişah tahkikat yaptı. Soruşturmanın selameti için Pîrî Mehmed Paşa vezirlik görevinden alındı. Yavuz bazı yeniçeri ileri gelenlerini toplayarak şöyle dedi: "Pîrî Paşa ile Hilmi Çelebi'nin evlerini yağma edenler kimlerin tahriki iledir? Elbette bana bildirmek zorundasını.." (Solakzâde, 1989: 38). Soruşturma neticesinde suçlu bulunarak saraya getirilip tutuklanan Vezir İskender Paşa ve Sekbanbaşı Balyemez Osman Ağa hemen idam edildiler. Kazasker Cafer Çelebi ise bizzat Padişah tarafından sorgulandıktan sonra idam edildi. (Solakzâde, 1989: 38; Erünsal, 2010: 354). Bu süreçte görevden alınan Pîrî Mehmed Paşa 3 gün sonra görevine iade edildi (Küçükdağ, 2017: 40).

Bütün bu olanlara rağmen padişahın Pîrî Mehmed Paşa'ya güveni sarsılmadı ve sürekli görüşmeye devam etti. Gelecek baharda seferin İran'a mı yoksa Mısır üzerine mi yapılacağı tartışılıyordu. İran Şiî olduğu için daha önce fetvalar alınmıştı ama Memlükler Sünnî bir İslam devletiydi. Onlarla savaş için de fetva alınması gerekiyordu. Yavuz durumu Paşa'ya sordu. Pîrî Mehmed Paşa, önce Misır işinin halledilmesi gerektiğini, bu gerçekleşirse İran meselesinin daha kolay çözüleceğini söyledi. Zenbilli Ali Efendi de bu minvalde bir fetva verdi (Turan, 1980: 404). Böylece Padişah kararını verdi ve bir ferman yayınlayarak hazırlıkların başlamasını istedi. Bazı tarihçiler bu süreçte Pîrî Mehmed Paşa'nın vezirlik görevinden alınmasını Memlükler üzerine sefere karşı çıkmasına bağlasalar da biz bu görüşe katılmıyoruz. Paşa'nın kısa bir süre sonra tekrar görevine iade edilerek İstanbul muhafızlı̆̆ı gibi önemli bir göreve getirilmesi de bu görüşümüzün doğruluğunu ispatlamaktadır. Yavuz 1516 yılı Haziran ayında ordusuyla Üsküdar'a geçti ve burada devlet adamları ile durumu müşavere etti. Burada Pîrî Mehmed Paşa şöyle dedi: "Bize lazım olan devletimizin kötülüğünü isteyenlere aşıkâne kılıç vurmaktır. Düşmanın peyda olduğu mahalde karşısında Sedd-i İskender gibi durmaktır." Paşa'nın bu sözleri Yavuz'un son derece hoşuna gitti ve şöyle dedi: “Bizim dahi gönlümüzden geçen bu idi. Berhudar ol." (Solakzâde, 1989: 38).

Yavuz isabetli görüşlerinden dolayı Pîrî Mehmed Paşa’yı dördüncü vezir rütbesiyle İstanbul muhafizı olarak sadaret kaymakamlığında görevlendirdi. Bu atamasıyla ona ne kadar güvendiğini gösterdi. Yavuz tarafından istenen Mısır'a denizden yardım gönderilmesinde gösterdiği gayret ve çalışkanlık ile bir defa daha göze girdi. Misır seferi sürecinde hem İstanbul'u son derece iyi yönetmesi, hem donanmayı geliştirmesi hem de Yavuz'un Mısır için istediği ihtiyaçları fazlasıyla temin etmesiyle 
idaredeki yeteneklerinin çok yüksek olduğunu ispatladı (Küçükdağ, 2017: 40-45). Pîrî Mehmed Paşa bu başarılarından dolayı Mısır Seferi devam ederken yeni kurulan Arap ve Acem Kazaskerliği görevine getirildi (Uzunçarşı11, 1984: 229).

Mısır Seferi dönüşünde Yavuz Sultan Selim, Mısır Beylerbeyliği görevine getirdiği Hayır Bey ile ilgili sarfettiği ihtiyatsız sözlerinden dolayı Sadrazam Yunus Paşa'yı idam ettirdi. Bir süre sadrazam atamadı. Suriye'ye gelince Pîrî Mehmed Paşa'yı Şam'a çağırdı ve 3 Aralık 1517 tarihinde sadrazamlığa getirdi (Uzunçarşı1l, 1984: 188). Bu görevlendirmeyi İstanbul'da tebliğ edebilecekken Paşa'yı Şam'a çağırmasının nedeni, onun tecrübelerinden faydalanarak yeni fethedilen bölgede düzeni sağlamak için olmalıdır. Pîrî Mehmed Paşa, Güneydoğu Anadolu ve Kuzey Irak bölgesini tamamen Osmanlı sınırları içine alan çalışmalarda bulundu. Bölgede zorla Şiîleştirilmeye çalışılan halkı ikna ederek Osmanlı'ya itaat etmelerini sağladı. Böylece doğunun Sünnî aşiretleri ile Safevîlere karşı bir ittifak oluşturmuş oldu. Bu ittifak Anadolu'nun Şiîleşmesini engelleyen en önemli tedbirlerden birisidir. Yavuz Sultan Selim onu doğuda bırakırken Şah İsmail ile direkt çatışmaya girmemesini isteyerek şöyle demişti: "Şah İsmail'i bu canibe çeküb üzerine gelmesi mukadder olursa zinhar karşı varub mukatele itmek sevdasına düşme... Berüye çek... Ulaklarla bana haber gönder. Birkaç gün içinde sana varub irişirüm.” (Celal-Zâde, 1990. 212-213).

Pîrî Mehmed Paşa, Şiî Safevî tehlikesi konusunda Yavuz'u sürekli bilgilendirdi ve uyardı. Yavuz Sultan Selim, Şiîlik konusunda Paşa'nın aşırı hassas olduğunu düşünüyordu. Hatta bu durum bir gece Yavuz'un rüyasına girdi ve Paşa'yı çağırtarak, “Bizim korkacak en büyük düşmanımız kimdir?” diye sordu. Pîrî Mehmed Paşa hiç düşünmeden, "Kızılbaş" diye cevap verdi. Bunun üzerine Yavuz eski dönemlerden itibaren atalarının ortak korkusu olan cevabı vererek; "Yanlış fehm etmişsin, bizim havfimız Tatar'dandır" cevabını verdi (Solakzâde, 1989: 106). Yavuz Safevîlerle aynı kaynaktan gelmesinden dolayı Halvetîlere de şüpheyle yaklaşıyordu. Yavuz'u bu noktada ikna eden ve harekete geçiren Pîrî Mehmed Paşa ve aynı aileden Zenbilli Ali Efendi olmuştur. Padişahı, Halvetîliğin Ehl-i Sünnet'e ters bir tavrı olmadığına ve Şiiliğin Anadolu halkını etkileyen Ehlibeyt propagandasına ancak bu kanaldan cevap verilebileceğine ikna etmişlerdir (Küçükdağ, 2017: 158-161).

Çaldıran'da Şah İsmail yenilmiş ama Safeviler ile yapılan savaş bitmemişti. Şiî daîler Anadolu'da propagandaya devam ederken yer yer Osmanlı orduları ile Safevîler arasında çatışmalar yaşanıyordu. Her iki devlet arasında bir barış antlaşması da imzalanmış değildi. Yavuz 19 Mayıs 1518 tarihinde Pîrî Mehmed Paşa'yı Güneydoğu Anadolu'ya göndererek bu sorunu çözmekle görevlendirdi. Pîrî Mehmed Paşa Diyarbakır'a gidip Bıyıklı Mehmed Paşa ile birleşerek Güneydoğu Anadolu ve Kuzey Irak’1 özellikle buralardaki Sünnî aşiretler ile anlaşarak Osmanlı sınırlarına kattı (Öztuna, 3, 1983: 258). İstihbarat çalışmalarına önem veren Paşa, İran Şahı'nın faaliyetlerini takip etti ve gerekli tedbirleri aldı. Sadece bunlarla kalmayıp yeni Osmanlı topraklarına katılan toprakların ve insanların tam bir tahririni yaptırdı. Böylece buraların halkı, vakıfları, malları ve toprakları mükemmelen kayıt altına alınmış oldu (Celal-Zâde, 1990: 220-221).

Osmanlı hükümdarları içinde ilk olarak Yavuz Sultan Selim İslam birliğini ve kutsal mekânların korunmasını temel hedef olarak belirlemiştir. Yavuz'un yaptığı faaliyetlere bakıldığı zaman bu hedef açık olarak görülebilir. Yavuz'u bu düşünceye götüren Şiî tehdidi kadar çok güvendiği Şeyhülislamı Zenbilli Ali Efendi ve Veziri Pîrî Mehmed Paşa olmuştur. Bu iki devlet adamına ve faaliyetlerine baktığımız zaman bu niyetlerini açık biçimde görüyoruz. Yavuz, Mısır seferinde iken Paşa'nın İstanbul'da yoğun bir şekilde gemi ve buna uygun top yapımına girişmesi bu hedefe matuftur. O sırada Portekiz donanması Ümit burnunu dolaşarak güneyden kutsal toprakları ve Hindistan'ı tehdit 
etmeye başlamıştı. Yavuz Sultan Selim, Portekiz tehdidine karşı Kızıldeniz'de savaşan Selman Reis'i önce Mısır'a çağırıp görüşmüş sonra da Pîrî Mehmed Paşa ile ortak çalışmaları için İstanbul'a göndermiştir (Küçükdağ, 2017: 43-45). Bütün bu nedenlerle Yavuz, Mısır alındıktan sonra Hindistan'daki ve Uzak Doğu'daki Müslümanlarla da ilgilenmeye başlamış ve Pîrî Mehmed Paşa'ya buralara gitmek üzere hazırlıklar yaptırmıştır. Pîrî Mehmed Paşa tarafından döktürülen o dönemin en gelişmiş topları Sumatra'ya gönderilmiştir (Küçükdăg, 2017: 50-53).

Yavuz Sultan Selim, Mısır seferini aynı zamanda kendisine nakledilen bir rüyaya dayanarak ilahi bir görev olarak da görmüştür. Şam'da verilen Cuma hutbesinde söylenen Hakimü'l-Haremeyn ifadesini kendisinin bizzat ayağa kalkarak Hadimü'l-Haremeyn olarak düzelttirmesi onun bu görüşünün bir yansımasıdır. Ayrıca Mısır seferi dönüşünde kendisine Sahibü'l-Haremeyn olarak gönderilen Kutsal Emanetleri yine aynı unvanla Hadimü'l-Haremeyn olarak teslim almıştır. Rüyada görülen Hz. Ali, Peygamberimiz adına, Haremeyn hizmetinin ona tevdi edildiğini bildirmiştir. Bunu dinleyen Yavuz'un gözlerinden yaş gelmiş ve şöyle demiştir: "Biz demez miyiz ki, bir canibe memur olmadan hareket etmemişiz. Ecdadımız vilayetten behremend olup kerametleri vardı."(Turan, 1980: 404).

Mısır seferinin en önemli neticesi hilafet ile saltanatın tekrar birleştirilmiş olmasıdır. Uzun süredir sembolik bir makamın ötesine geçmeyen halifelik Yavuz tarafından tekrar Peygamberimiz dönemindeki evrensel konumuna oturtulmuştur. Yavuz tarafından İstanbul'a getirilen son Abbasî Halifesi Mütevekkil, Ayasofya'da yapılan bir törenle bu görevi Yavuz Sultan Selim'e devretmiştir (Turan, 1980: 407). Osmanlı Padişahları'nın halifeliği birçokları tarafından tartışılsa da dünyevî güce de sahip olmasıyla Peygamberimiz ve ilk dört halife dönemine en yakın uygulamalardan birisi olduğu tarihi bir realitedir. $\mathrm{Bu}$ paradigmatik değişimin gerçekleşmesine dönemin veziriazamı ve şeyhülislamının büyük etki olduğu açıktır.

Yavuz Sultan Selim, İran seferi ve Mısır seferi ile ilgilendiği için Batı’yı biraz ikinci planda bırakmıştı. Yavuz'un asıl amacı aradaki ayrık otlarını temizleyerek Hindistan ve Türkistan'a kadar İslam birliğini sağlamaktı. Bundan faydalanan Hıristiyan devletler, Osmanlı sınırlarına tecavüzde bulunmaya başladılar. Doğu meselesini büyük oranda halleden Yavuz, Pîrî Mehmed Paşa'nın de teşvikiyle, bunlara hadlerini bildirmeye karar verdi. Önce Mısır'a gidiş gelişlerde ve hac yolculuğunda büyük problemler oluşturan Rodos'a karşı harekete geçmeyi planladı. Fakat donanmanın ve hazırlıkların bunun için yeterli olmadığına karar verdi. Tam bu süreçte birgün Eyüp Sultan Türbesi'ni ziyaret ederken Donanma Komutanı Cafer Ağa'nın kadırgasının denize indirilerek toplar atılmaya başlandığını gördü. Henüz sefere karar verilmemişken böyle bir tedbirsizlik yapılması padişahı son derece kızdırdı ve Cafer Ağa'nın katli için emir verdi. Durumdan haberdar olan Pîrî Mehmed Paşa şefaatçi olarak bunu engelledi (Küçükdağ, 2017: 92).

Yavuz Sultan Selim bütün fetihlerini tamamlayıp İstanbul'a döndüğü zaman Pîrî Mehmed Paşa'ya şöyle bir soru sorar: “Pîrî lalam! Allah'ın emri ile Mısır' ' fetheyledik. Hadimü'l-Haremeyn unvanıyla muazzez olduk. Her gittiğimiz tarafta fetihler nasip oldu ve emrimize muhalefet edecek kimse kalmadl. Bu vaziyette devletin zevali ihtimali var mıdır? Bu soruya Pîrî Mehmed Paşa şu cevabı verir: "Yüce cedlerinizin koydukları kanun ve kaideler icra olundukça bu devletin zevali muhaldir.” (Turan, 1980: 409).

Yavuz Sultan Selim doğudaki problemleri büyük oranda hallettikten sonra batıya yöneldi. Önce kendisini hararetle Avrupa'ya sefere teşvik eden Sadrazamı Pîrî Mehmed Paşa'yı orduyla önden Edirne'ye gönderdi. Kendisi de Ağustos 1520'de yola çıktı ve Çorlu yakınlarında babasıyla savaştığı 
yerde konakladı. Hasta idi ve hekimler tedavi etmeye çalışıyorlardı. Durumu ağırlaşınca Pîrî Mehmed Paşa'yı hemen yanına çağırttı. Başta Sadrazam olmak üzere vezirleri ile vedalaştı ve aynı gece sabaha karşı 22 Eylül 1520 tarihinde vefat etti (Öztuna, 3, 1983: 258).

\section{YAVUZ SULTAN SELIM VE ZENBİLLİ ALİ CEMALÎ EFENDİ}

Zenbilli Ali Cemalî Efendi Osmanlı Devleti’nin zirvesini teşkil eden II. Bayezid, Yavuz ve Kanunî dönemlerinin en etkili şahsiyetlerinden birisidir. Olayların gelişimine bakılırsa Zenbilli Ali Cemalî Efendi, Pîrî Mehmed Paşa'nın babası olan amcaoğlu Cemal Halvetî gibi II. Bayezid üzerinde etkisi olan âlimlerdendi. II. Bayezid 1481 yılında Osmanlı tahtına oturunca onu Veliaht Şehzade Ahmed'i eğitmek ve yanında bulunmak üzere Amasya'ya gönderdi. Şehzade Ahmed'in Şiî tehdidine önem vermemesinden dolayı Zenbilli Ali Efendi kısa süre sonra Amasya'yı terk ederek İstanbul'a döndü (Küçükdağ, 2018: 53).

II. Bayezid tarafından 1503 yılında Şeyhülislamlık görevine getirilen bu değerli âlim Yavuz tarafından da görevinde bırakıldı (Küçükdağ, 2018: 49). 1511 yılında gerçekleşen kardeşler arası taht mücadelesinde ulemanın başı olarak bütün gücüyle Yavuz'u desteklediği için her zaman onun yakın ekibinde bulundu (Öztuna, 3, 1983: 203). Zenbilli Ali Efendi Osmanlı hukukunun ve kanunnamelerinin en önemli mimarlarının başında gelir. Cesur olarak doğruları söylemekten çekinmemiş ve bu durum nedeniyle Yavuz Sultan Selim ile farklı düşündükleri birçok ilginç olay yaşanmıştır. Ama adaletten şaşmaması ve pratik çözümleri onu Yavuz'un en fazla desteklediği ve görüşüne değer verdiği kişilerden birisi ve belki de birincisi haline getirmiştir. Özellikle Pîrî Mehmed Paşa ile beraber Maliye memurlarının ve tüccarların haksız yere cezalandırılmalarını engellemesi Yavuz döneminde zor cesaret edilebilecek olaylardandır. Yavuz'un 100 civarında hazine memurunun idamı için ferman verdiğini duyunca hemen olaya müdahale etmiş ve engellemiştir. Sadece bununla yetinmeyerek Padişaha şöyle deme cesaretini göstermiştir: "Ahirete müteallik olan hizmeti eda ittim. Mürüvvete müteallik bir sözüm dahi kaldl.” (Küçükdă̆, 2018: 60-61).

Müslüman olmayanların zorla Müslümanlaştırılmasına karşı çıkması olayı da onun Yavuz'a karşı direndiği olaylardandır. Birgün bütün Gayrimüslimleri zorla Müslümanlaştırmak niyetiyle Yavuz, Zenbilli Ali Efendi'ye şu soruyu sorar: “Bütün dünyayı fethetmekten ve milletleri Íslam'a getirmekten hangisi daha makbuldür?” Bu soruya ünlü Şeyhülislam sonuçlarını düşünmeden şöyle cevap verir: "Gayrimüslimlerin Müslüman edilmeleri daha makbul ve rıza-yl ilahiye daha muvafik olur." (Küçükdağ, 2017: 159-160). Bu fetva üzerine Yavuz, hemen harekete geçerek Sadrazam Pîrî Mehmed Paşa'ya bu yönde emir verir. Kiliselerin camiye çevrilmesi, Hiristiyan ayinlerinin yasaklanmasını ve Müslüman olmayanların öldürülmesini içeren bu emir sadrazamı dehşete düşürür ve derhal kuzeninin yanına koşar. Cemalî ailesinin iki önemli kişiliği beraberce Padişahın yanına giderek böyle bir uygulamanın dinin maslahatına uygun olmayacağına onu ikna edip büyük bir facianın önüne geçerler. (Küçükdağ, 2017: 160).

Hukukun üstünlüğünü korumada Pîrî Mehmed Paşa ile birlikte Osmanlı tarihinin en ideal ikilisini oluşturmuşlardır. Padişahların sınırsız sayılabilecek yetkilerini, dinin adalet anlayışı ile sınırlandırmıştır. Fatih döneminde Şeyhülislam Molla Hüsrev ile başlatılan kanunlaştırma çalışmalarını Zenbilli Ali Efendi devam ettirmiştir. Böylece Osmanlı hukukunun en önemli mimarları arasına girmiştir. Meselelere getirdiği hızlı çözümlerle geciken adaletin adalet olamayacağını herkese göstermiştir. Statükocu ve tekrarcı olmayıp yeniliklere açık bir kişiliğe sahipti. Bir Osmanlı 
Şeyhülislamı olarak en önemli görevinin meselelere yeni çözümler üretmek olduğunu düşünmüştür (Akgündüz, 1990: 225).

Yavuz Sultan Selim bütün sertliğine rağmen onun bu özelliklerinden dolayı genellikle kararlarına sayg1 göstermiştir. Birgün hiç çekinmeden Yavuz’un yüzüne karşı çok kararlı bir şekilde şöyle demişti: "Ĕger şeriata aykırı kararlar verirsen, ben de senin haline fetva veririm." Yine bir gün Kanunî saray bahçesindeki ağaçlara zarar veren karıncalarla ilgili olarak manzum şekilde şu soruyu sormuştu: "Dırahtı sarmış olsa eğer karınca, Zarar var mı karıncayı kırınca." Zenbilli Ali Efendi bu soruya verdiği müthiş cevapta şiirdeki yeteneğini de ortaya koymuştu: "Yarın hakkın divanına varınca, Süleyman'dan hakkın alır karınca."

Zenbilli Ali Efendi sadece bürokratik görevleriyle yetinmemiş yazdı̆̆ı kitap ve risalelerle de halk1 dinî ve ahlakî konularda aydınlatmaya çalışmıştır. Mütefekkir ve serbest düşünceli bir kişiliğe sahipti. Buna rağmen Şiîlik tehdidinin ciddiyetini ilk görenlerden birisiydi. Sünnî inancı Şiîliğe karşı savunmayı bütün Cemalî Ailesi üyeleri gibi hayat memat meselesi haline getirmişti. Bu düşüncesi nedeniyle Yavuz'a yaklaşırken Şehzade Ahmed ile arası açılmıştır. Şehzade Ahmed Şiî tehdidini görmezden geldiği için Amasya Müftülügüüü ve müderrisliği terk ettiğini söyleyenler vardır (Küçükdağ, 2018: 52-53).Şî̂ Safevîler ile Sünnî Memlükler arasındaki ittifak görüşmeleri Yavuz'u çok rahatsız etmiş ve onlarla savaş için Zenbilli Ali Efendi’ye danışmıştır. Kendisine Safevîler ile savaşın doğru olup olmadığına dair Yavuz tarafından soru sorulup fetva istenince savaşmanın caiz olduğuna dair şu fetvayı vermiştir: "Mülhide yardım eden mülhiddir.” (Solakzâde, 1989: 110).

Zenbilli Ali Efendi sürekli okuyan ve kendisini yenileyen bir âlimdi. İslam âlemindeki önemli âlimleri takip eder ve bunların eserlerini en hızlı şekilde temin ederdi. Bundan dolayı bazı eserleri Osmanlı Devletine ilk getiren kişi olarak kabul edilir. Hac yolculuğu sırasında âlimlerinin methini duyduğu Mısır'a uğramış ve oradan İbn Hümam'ın Fethü'l-Kadîr isimli eserinin müellif hattını ve Kaşanî'nin Bediu's-Sanâyî isimli eserini ilk olarak İstanbul'a getiren kimse olmuştur (Küçükdağ, 2018: 68). Yavuz Sultan Selim bütün sertliğine rağmen onun bu özelliklerinden dolayı genellikle kararlarına uyardı.

Zenbilli Ali Efendi tasavvufa meyilli idi (Küçükdağ, 2018: 57; Ata, 2016: 142). Elbette yakın akrabasından amcaoğlu Cemal Halvetî ve Cemaleddin İshak Karamanî gibi pekçok tasavvuf önderi olması onun bu davranışında etkili olmuştur. Ama o yakın akrabalarına değil daha ilmî bir kimliğe sahip Zeyniyye Tarikatı'nın İstanbul'daki temsilcisi Konyalı Şeyh Vefa'ya (ö.1491) intisab etmiştir. Çağdaşı olan Sinan Paşa, Molla Lütfi ve Bursalı Hocazâde gibi âlimlerin de bu şeyhe bağlı oldukları bilinmektedir. Cemalî Ailesi üyeleri hangi pozisyonda olurlarsa olsunlar eser yazmışlar ve medreseyle yakın temas içinde olmuşlardır. Zenbil olayında olduğu gibi pratik çözümler bulmuşlardır. Zenbil dediğimiz ufak sepet belki de Zenbilli Ali Efendi'nin hızlı ve tarafsız adaleti sağlamak için geliştirdiği bir çözümdü. Bu durum Zenbilli Ali Efendi'nin bilim ve teknikle içiçe olmasının açık bir göstergesidir (Küçükdağ, 2018: 57).

Osmanlı Devleti'nde bazı kurumlar Zenbilli Ali Efendi'nin düzenlemeleriyle gerçek yerine oturmuştur. Örneğin şeyhülislamlığın veziriazamlıktan sonraki en yetkili ikinci makam haline gelmesi onun uygulamaları ve fetvaları ile gerçekleşmiştir (Öztuna, 10, 1983: 246). Zenbilli Ali Efendi'den önce şeyhülislamlar gerek görüldügünde divan toplantılarına çağrılırken ondan itibaren istedikleri zaman divan toplantılarına katılmışlar ve görüşlerini beyan ederek kararlara müdahale etmişlerdir. Ayrıca onun şeyhülislam olmasından itibaren bu görevde bulunanlar medreseler ile de 
bizzat meşgul olup ders ve imtihanlara katılmışlardır. Bizzat onun tarafından birçok öğrenci yetiştirilmiş ve sonraki dönemde önemli görevlere gelmişlerdir (Küçükdağ, 2018: 63).

\section{SONUÇ}

I. Selim çocukluğundan itibaren Amasya ve İstanbul'da Cemalî Ailesi mensuplarını yakından tanıma imkânına sahip olmuştur. Bu aileden olan ve Şiî tehdidini bir akrabalarını kaybederek yakından tanıyan Pîrî Mehmed Paşa ve Zenbilli Ali Efendi, Yavuz'un doğuya yönelmesinde en önemli teşvikçileri ve destekçileri durumuna gelmişlerdir. Yavuz Sultan Selim hükümdarlığı boyunca onları görevlerinde tuttuğu gibi görüşlerine de son derece itibar etmiştir. Vefat ettiği tarihe kadar görevde tuttuğu en önemli görevliler devletin iki ve üç numarası Pîrî Mehmed Paşa ve Zenbilli Ali Efendi olmuştur. Yaklaşık 8 yıllık hükümdarlığında Osmanlı Devleti'ni üç kata yakın büyütmüş ve devleti sağlam temeller üzerine oturtmuştur. Meydana getirdiği son derece disiplinli sitemle, hayatının önemli bir bölümünü seferlerde geçirmesine rağmen, devlette neredeyse hiçbir otorite boşluğu oluşmamıştır. Atadığı görevlileri son derece iyi seçmiş ve görevini aksatanlara karşı son derece sert davranmıştır. Başta vezirler olmak üzere birçok bürokratı idam ettirmekten çekinmemiştir. Ama sayg1 duyduğu bu iki devlet adamını vefatına kadar görevlerinde bırakarak onlara olan güvenini göstermiştir. 


\section{KAYNAKÇA}

Akgündüz, Ahmet (1990). Osmanlı Kanunnâmeleri ve Hukuk Tahlilleri. C. I, İstanbul: Fetih Vakfı Yayınları.

Ata, Ramazan (2016). Selçukludan Osmanlıya Aksaray Okulu. Konya: Hüner Yayınevi.

Bayram, Mikail (2008). “Alâeddin Keykubad'ın İlmî Şahsiyeti”, I. Alâeddin Keykubad ve Dönemi Sempozyumu Bildirileri, 6-7 Kasım 2008, Konya: Konya Valiliği İl Kültür ve Turizm Müdürlüğü Yayınları.

Celal-Zâde, Mustafa (1990). Selim-Nâme. Haz. Ahmet Uğur-Mustafa Çuhadar. Ankara: Kültür Bakanlığı Yayınları.

Downey, Fairfax (1975). Kanuni Sultan Süleyman. çev. Enis Behiç Koryürek. İstanbul: Kültür Bakanlığı Yayınları.

Erünsal, İsmail E. (2010). “Tâcizâde Cafer Çelebi”, DİA. C. 39, İstanbul: Türkiye Diyanet Vakfı Yayınları.

Konyalı, İ. Hakk1 (1974). Âbideleri ve Kitabeleri ile Niğde-Aksaray Tarihi. C. I. İstanbul: Fatih Kitabevi.

Küçükdağ, Yusuf (2018). Cemali Ailesi. Aksaray: Aksaray Belediyesi Kültür Yayınları.

Küçükdağ, Yusuf (2017). Pîrî Mehmed Paşa. Aksaray: Aksaray Belediyesi Kültür Yayınları.

Öztuna, Yılmaz (1983). Büyük Türkiye Tarihi. C. 3. İstanbul: Ötüken Yayınevi.

Solakzâde, Mehmed Hemdemî Çelebi (1989). Solakzâde Tarihi. çev. Vahid Çabuk. C. 2. Ankara: Kültür Bakanlığı Yayınları.

Tansel, Selahattin (1969). Yavuz Sultan Selim. Ankara: Milli Eğitim Bakanlığı Yayınları.

Turan, Osman (1980). Türk Cihan Hâkimiyeti Mefkûresi Tarihi. İstanbul: Nakışlar Yayınevi.

Uzunçarşılı, İ. Hakkı (1984). Osmanlı Devleti’nin Merkez ve Bahriye Teşkilatı. Ankara: Türk Tarih Kurumu Yayınları. 